\title{
Chronic Granulomatous Disease
}

\author{
Steven M. Holland
}

Published online: 9 June 2009

(C) Humana Press Inc. 2009

\begin{abstract}
Chronic granulomatous disease (CGD) was first described in the 1950s and has become a paradigm for genetic neutrophil diseases. It is characterized by recurrent infections with a narrow spectrum of bacteria and fungi as well as a common set of inflammatory complications most notably including inflammatory bowel disease. Over the last half century major advances in management have profoundly altered the major clinical issues and the life expectancy of CGD. With X-linked and autosomal recessive forms, it has been an important disease for the development of bone marrow transplantation and gene therapy. Some of the recent developments in infectious syndromes, inflammatory complications, and curative approaches are discussed in this review.
\end{abstract}

Keywords Chronic granulomatous disease (CGD) . X-linked disease $\cdot$ NADPH oxidase $\cdot$ Nitroblue tetrazolium (NBT) · Dihydrorhodamine oxidation (DHR) · Aspergillus · Granulibacter $\cdot$ Burkholderia

Chronic granulomatous disease (CGD) was first described in 1954 [1] and 1957 [2], but was not well-characterized until 1959 [3], when it was initially termed fatal granulomatous disease of childhood. The obvious limitations of that name became apparent and it is now simply referred to as CGD. Although originally thought to be only an X-linked disease that appeared exclusively in males, its recognition in girls in 1968 led to the determination of autosomal recessive forms as well [4]. Over the last 50 years, we have learned much about CGD, converting it from a disease of tragic and early complications to a disease of chronic management and

S. M. Holland $(\bowtie)$

Laboratory of Clinical Infectious Diseases,

National Institute of Allergy and Infectious Diseases,

National Institutes of Health,

Department of Health and Human Services,

CRC B3-4141, MSC 1684,

Bethesda, MD 20892-1684, USA

e-mail:smh@nih.gov high survival [5]. It has served as a paradigm for the primary immune defects that are not part of the severe combined immunodeficiency group and has guided us in understanding the importance of oxygen metabolism in the phagocyte, the vasculature, and the brain. Following its genetic determination, it has provided an important target for gene therapy and has been a leading disease for the development of bone marrow transplantation for nonmalignant diseases. Therefore, in the 50th year anniversary of its comprehensive description, it is fitting to take stock of the disease, its management, and its implications.

CGD is a single disease with four genetic etiologies, reflecting that all four proteins go into the composition of the single enzyme complex that catalyzes the transfer of an electron from cytoplasmic NADPH to molecular oxygen (5; OMIM\# 306400, 233690, 233700, 233710). Since NADPH is oxidized by this electron harvest, the enzyme complex is known as the NADPH oxidase. Although this process takes place mostly in the phagocyte, it is not exclusively there; therefore, defects in this enzyme have subtle effects in other tissues as well. Furthermore, although the components of the NADPH oxidase are usually considered as phagocyte proteins, in fact only gp $91^{\text {phox }}$ is very phagocyte-specific, while the other autosomal components are expressed elsewhere, as well [6]. The components are broken into membrane bound (cytochrome b558, comprised of gp91 $1^{\text {phox }}$ and $\mathrm{p} 22^{\text {phox }}$ ) and cytosolic (p47 $7^{\text {phox }}$ and $\mathrm{p} 67^{\text {phox }}$ ) components. The cytochrome components gp $91^{\text {phox }}$ and $\mathrm{p} 22^{\text {phox }}$ require each other for expression in the phagocyte. One implication of this is that since $\mathrm{p} 22^{\text {phox }}$ is expressed in other tissues and gp91 ${ }^{\text {phox }}$ is not, there are other partners that $\mathrm{p} 22^{\text {phox }}$ and the other members of the NADPH oxidase join with in other tissues, which are other members of the Nox family of proteins. Therefore, individuals who have autosomal recessive forms of CGD may also have subtle abnormalities in tissues other than leukocytes where these proteins are expressed, such as vascular endothelium or renal epithelium. 
In addition to the structural components of the NADPH oxidase, there are the critical regulatory components $\mathrm{p} 40^{\text {phox }}$ and rac. On cellular activation, the cytosolic components $\mathrm{p} 47^{\text {phox }}$ and $\mathrm{p} 67^{\text {phox }}$ are phosphorylated and bind tightly together. In association with $\mathrm{p} 40^{\text {phox }}$ and rac, these proteins combine with the cytochrome complex (gp91 ${ }^{\text {phox }}$ and $\mathrm{p} 22^{\text {phox }}$ ) to form the intact NADPH oxidase. An electron is taken from NADPH and donated to molecular oxygen, leading to the formation of superoxide. In the presence of superoxide dismutase, this is converted to hydrogen peroxide, which, in the presence of myeloperoxidase and chlorine in the phagosome, is converted to bleach. Until recently, the metabolites of superoxide themselves were thought to be the critical mediators of bacterial killing. However, Reeves and coworkers [7] have shown that phagocyte production of reactive oxygen species leads to microbial killing through the activation of certain primary granule proteins inside the phagocytic vacuole. This new paradigm for NADPH oxidasemediated killing suggests that reactive oxidants are working more as intracellular signaling molecules, leading to the activation of other nonoxidative pathways, rather than causing killing directly. One implication of this understanding is that, in the absence of NADPH oxidase activity, the same enzymes are present but hypofunctional, whereas, upon cellular stimulation, they are more highly activated. This suggests a spectrum of microbicidal activity that can be regulated to distinct degrees, rather than distinct types, such as oxidative and nonoxidative pathways and mechanisms [5].

Mutations in all of the four structural genes of the NADPH oxidase have been found to cause CGD. Mutations in gp9 $1^{\text {phox }}$ account for about $65 \%$ of cases, mutations in $\mathrm{p} 47^{\text {phox }}$ about $25 \%$, and the remainder is divided between $\mathrm{p} 67^{\text {phox }}$ and $\mathrm{p} 22^{\text {phox }}$; there are no autosomal dominant cases of CGD. Estimates of frequency are hard to verify, but a large voluntary retrospective study in the United States suggested rates of around 1:200,000 live births. Rates in other countries are roughly similar but vary somewhat depending on the ethnic practices and degrees of intermarriage: Sweden 1/450,000; Japan 1/300,000; Israeli Jews $1 /$ 218,000; Israeli Arabs 1/111,000 (reviewed in [8]). Clinically, CGD is quite variable, but the X-linked gp91 ${ }^{\text {phox }}$ deficient form appears more severe with earlier presentation and diagnosis and more severe infections and earlier death than the $\mathrm{p} 47^{\text {phox }}$-deficient form $[5,8]$. Large series of $\mathrm{p} 22^{\text {phox }}$ and $\mathrm{p} 67^{\text {phox }}$ patients are unavailable, so it is not entirely clear which form they are more similar to. The majority of patients are diagnosed as toddlers and young children $[5,8]$.

Infections and granulomatous lesions are the usual first manifestations. The lung, skin, lymph nodes, and liver are the most frequent sites of infection. In North America, the overwhelming majority of infections in CGD are due to only five organisms: Staphylococcus aureus, Burkholderia cepacia, Serratia marcescens, Nocardia, and Aspergillus. In other parts of the world, Salmonella, Bacille CalmetteGuerin (BCG), and tuberculosis are also important $[5,8,9]$. In contrast to patients with severe combined immunodeficiency or defects in the interferon (IFN)-gamma receptor pathway, CGD patients develop severe localized BCG rather than disseminated infection. Trimethoprim/sulfamethoxazole prophylaxis has reduced the frequency of bacterial infections in general and staphylococcal infections in particular. On prophylaxis, staphylococcal infections are essentially confined to the liver and cervical lymph nodes [5]. Staphylococcal liver abscesses encountered in CGD are dense, caseous, and difficult to drain, requiring surgery in almost all cases [10]. Until recently, fungal infections, typically due to Aspergillus species, were the leading cause of mortality in CGD [9]. However, the advent of highly active antifungal therapy with the azole antifungals itraconazole, voriconazole, and posaconazole has changed the face of fungal infections in CGD. Mortality from Aspergillus fumigatus infection in CGD is now uncommon and, therefore, overall mortality is diminished.

Overall survival in CGD has changed remarkably over the last decade and is now around $90 \%$, stretching well into adulthood. However, survival is heavily influenced by several distinct factors. Not surprisingly, the period in which the diagnosis was made is crucial to understanding the likelihood of survival. Patients diagnosed before the advent of antifungal azole agents had a very different trajectory of disease, as reflected by the very poor survival of patients into their $30 \mathrm{~s}$ and $40 \mathrm{~s}$ in those series $[9,11]$. However, following the introduction of itraconazole in the late 1990s and its proof as a potent antifungal prophylactic in 2003 [12], as well as the introduction of more active agents, fungal mortality in particular and CGD mortality overall have plunged. This is easily appreciated in the examination of survival rates in several of the large cohorts reported $[11,13,14]$. Access to care and the expertise of caregivers are also clearly important. One Japanese study showed a $90 \%$ survival rate for patients followed up at single center [15]. Similarly, in a longitudinal analysis of 47 patients, Muoy et al. [16] found an 8-year survival rate of $70.5 \%$ for children born before 1978 but a $92.9 \%$ survival rate for those born later. Winkelstein et al. [9] found mortality for the X-linked form of the disease of about 5\%/ year, compared to $2 \% /$ year for the autosomal recessive varieties, both of which numbers preceded the introduction of oral antifungals. Therefore, it seems very likely that overall mortality from infection in CGD is relatively low and will improve.

In contrast to mortality, the morbidity of recurrent infections and their impact on the child, the family, and 
end-organ function remain major issues. Several large studies have shown a relatively similar rate of infection of around $0.3 /$ year $[11,13]$. That is, most patients are still experiencing at least one severe infection every 3-4 years, whether bacterial or fungal. This rate has remained rather constant over the last 10 years, despite improved orally available antibiotics and antifungals and increasing familiarity with the disease. This may, therefore, reflect either a relative minimum rate driven by inescapable environmental exposures or the reality of maintaining long-term prophylaxis in the setting of childhood, adolescence, and young adulthood with a disease that is only intermittently intrusive. However, even though imperfect, it is clear that antibacterial prophylaxis is helpful and effective [17].

Several infections are distinctive to CGD and important to consider and recognize. Among gram-negative bacteria, B. cepacia complex organisms are common causes of pneumonia and infrequently sepsis [9]. The closely related Burkholderia gladioli has also been described in CGD [18]. Interestingly, these organisms are almost exclusively encountered in CGD and cystic fibrosis, but rarely in other forms of lung disease, suggesting a pathophysiologic link between these two diseases, although this has been elusive so far [19]. Chromobacterium violaceum causes sepsis in CGD and is found in brackish waters, such as those around the Gulf of Mexico in the United States [20]. Francisella philomiragia causes sepsis in CGD and is also found in brackish waters, such as the Chesapeake Bay in the United States [21]. Recently, a novel organism has been described exclusively in CGD, Granulibacter bethesdensis [22]. This organism causes necrotizing lymphadenitis and can cause sepsis [23]. It is unusual in that it has been documented over many months in CGD patients and can have latent and active phases, similar to tuberculosis. It has been found in CGD patients from the United States, Panama, and Spain, suggesting that it is widely distributed in the environment.

Among fungi, the list of unusual infections is even more lengthy and obscure, since there are so many species of fungi and so relatively few are medically important. The filamentous molds Paecilomyces variotti and Paecilomyces lilacinus are rare outside of CGD [24]. Aspergillus nidulans is highly pathogenic in CGD but not in any other patient group, including transplant recipients [25]. A newly recognized species, Neosartorya udagawae, has been shown to cause a characteristically chronic and progressively invasive infection in CGD, but is rarely encountered in other groups [26]. In contrast to these rare organisms that are virtually pathognomonic for CGD, other fungi are rarely encountered. The endemic dimorphic mold infections histoplasmosis, blastomycosis, and coccidioidomycosis do not occur in CGD, nor does cryptococcosis. Mucormycosis only seems to occur in CGD when significant immunosuppression, such as sustained high dose steroids, has been used [27]. Therefore, the microbiology of infection should be vigorously pursued and can be highly suggestive of CGD as the underlying cause.

Fungi elicit an exuberant inflammatory response in CGD lungs, which is independent of whether the fungi are alive or dead, and in mice, even boiled Aspergillus lead to striking pulmonary inflammation [28]. The recently recognized syndrome of "mulch pneumonitis" embodies these phenomena and can either complicate previously recognized CGD or be its initial presentation [29]. In humans, this syndrome is caused by exposure to aerosolized decayed organic matter, such as mulch, hay, or dead leaves. The clinical syndrome is very distinct: a previously well child or adult spreads mulch, turns compost, or clears moldy leaves, inhaling numerous fungal spores and hyphae; about 2 days later, a syndrome similar to pulmonary hypersensitivity begins with fever and dyspnea; chest radiographs show diffuse interstitial infiltrates; bronchoscopy is usually uninformative but may yield Aspergillus; lung biopsy shows acute inflammation with necrotizing granulomata and fungi. Successful treatment of this syndrome is with simultaneous antifungals for the infection and steroids for the inflammation [29]. Counterintuitive though it may seem, the use of steroids is crucial for maintaining ventilation and may be life-saving. This syndrome and, therefore, CGD as the underlying diagnosis, should be considered in all cases of otherwise unexplained diffuse infiltrates or Aspergillus pneumonitis, especially with acute onset and hypoxia.

The inflammatory complications of CGD are most prominent in the gastrointestinal and genitourinary tracts. Esophageal, jejunal, ileal, cecal, rectal, and perirectal involvement with granulomata mimicking Crohn's disease have been described [30, 31]. Gastric outlet obstruction is especially common and may be the initial presentation of CGD. In a large survey of CGD patients followed up at the $\mathrm{NIH}$, Marciano et al. found that $43 \%$ of X-linked CGD patients had symptomatic biopsy-proven inflammatory bowel disease (IBD). In contrast, only $11 \%$ of $\mathrm{p} 47^{\text {phox }}$ deficient patients had IBD [30]. However, growth rates were equally diminished below the mean United States levels for both IBD-affected and IBD-unaffected patients. Since gastrointestinal endoscopy was only performed for cause on symptomatic patients, we do not know whether the mild growth retardation seen in most CGD patients was due to IBD in all cases or due to some other CGDassociated feature of the disease. Perirectal disease is especially prominent in CGD [31].

Treatment of CGD IBD is vexing. Steroids are effective but have obvious risks and complications including growth retardation, osteoporosis, and infection risk. However, at the doses typically used in CGD for maintenance, infections are rarely an issue. In contrast, the newer TNF-alpha 
blocking agents, infliximab and adalimumab, are highly effective and rapidly suppress bowel symptoms, but carry a very significant risk of infection. In our experience, TNFalpha inhibitors predispose to characteristic CGD pathogens, only more severe episodes. Our current practice is to initiate therapy for proven IBD in CGD with prednisone $1 \mathrm{mg} / \mathrm{kg} /$ day for 1 to 2 weeks and then slowly taper to $0.1-$ $0.25 \mathrm{mg} / \mathrm{kg} /$ day over 1 to 2 months. Sometimes, children can be taken off prednisone, but the relapse rate is very high and retreatment typically requires reinitiation of the higher dose. Therefore, after the first recurrence or relapse, we usually add an antimetabolite such as imuran along with salicylic acid derivatives. Local treatments such as steroid enemas and rectal creams can also be highly effective.

In addition to the bowel involvement in CGD, liver involvement is pronounced and important. Liver abscess occurs in around $35 \%$ of patients and is difficult to treat successfully without surgery [10]. With surgery, cure of liver abscess is common, but unfortunately so is subsequent reinfection, suggesting that either there are CGD patients who are innately predisposed to liver abscess or that the fact of having had a liver abscess alters hepatic metabolism and architecture in a way that makes subsequent infection more likely. Further complicating liver function in CGD is the recent report of high rates of portal venopathy and nodular regenerative hyperplasia, both of which may contribute to portal hypertension, splenomegaly, and splenic sequestration [32]. This latter point is noteworthy because further study has shown that the decline in platelet count, which is linked to splenomegaly, is also a strong predictor of mortality in CGD [33]. The reasons why microvascular disease in the liver should be so common are unclear. However, chronic drug effects, liver enzyme elevations, and recurrent infections are obvious risks for liver dysfunction. Why platelet count declines are such strong harbingers of complications is unclear, but hematologic data are easy to acquire, well-performed almost everywhere, and easily tracked over time [33].

Genitourinary manifestations of CGD include bladder granulomata, ureteral obstruction, and urinary tract infection. All patients with granulomata of the bladder or stricture of the ureter in an early series had defects of the membrane component of the NADPH oxidase (gp91 ${ }^{\text {phox }}$ and $\mathrm{p} 22^{p h o x}$ ) [34]. Subsequent descriptions have confirmed the occurrence of pseudotumors of the bladder [35-37] and eosinophilic cystitis [38].

The diagnosis of CGD is usually made by direct measurement of superoxide production, ferricytochrome $c$ reduction, chemiluminescence, nitroblue tetrazolium (NBT) reduction, or dihydrorhodamine oxidation (DHR). DHR is preferable because of its relative ease of use, its ability to distinguish X-linked from autosomal patterns of CGD on flow cytometry, and its sensitivity to even very low numbers of functional neutrophils [39]. However, one condition that can give a falsely abnormal DHR is myeloperoxidase deficiency [40]. In the case of myeloperoxidase deficiency, DHR activity can look like X-linked CGD, while NBT and ferricytochrome $c$ testing are normal. This is attributed to intracellular (DHR) compared to extracellular (NBT) superoxide release and dye activation. The syndrome of synovitis, acne, pustulosis, hyperostosis, and osteitis has also been associated with abnormal intracellular generation of oxidants [41]. Glucose-6phosphate dehydrogenase (G6PD) deficiency may also lead to a decreased respiratory burst and increased susceptibility to bacterial infections [42]. However, G6PD deficiency is most often associated with some degree of hemolytic anemia, while CGD is not.

The X-linked carriers of gp91 $1^{\text {phox }}$ have two populations of phagocytes: one that produces superoxide and one that does not, giving carriers a characteristic mosaic pattern on oxidative testing. Infections are not usually seen in female carriers unless the normal neutrophils are below $5-10 \%$. However, cases of severe skewing of X-inactivation have been reported in which females have virtually no detectable normal cells; these carriers are at risk for CGD type infections [43]. There are reports suggesting that the balance of wild-type to mutant cells may vary over time in the same woman, but this has not been rigorously proven yet, as likely as it may appear to be [43]. Discoid lupus erythematosus-like lesions, aphthous ulcers, and photosensitive rashes have been seen in gp $91^{\text {phox }}$ carriers. Similarly, screening of patients with discoid lupus erythematosus detected a significant number of previously unsuspected CGD carriers [44-46].

Immunoblot and flow cytometry can be used to infer the specific genotype. However, molecular determination of specific mutations, available from various research and commercial laboratories, is necessary for prenatal diagnosis. With further study, there may be genotype/phenotype correlations that predict outcomes and thereby might help in genetic counseling as well as in the consideration of bone marrow transplantation. Male sex, earlier age at presentation, and increased severity of disease suggest X-linked disease, but these are only rough guides. The precise gene defect should probably be determined in all cases, but at this point, it does not have a profound impact on management. Autosomal recessive $\mathrm{p} 47^{\text {phox }}$ CGD appears to have a significantly better prognosis than X-linked disease $[9,11]$.

Management of CGD is predominantly with prophylactic antibiotics and antifungals and IFN-gamma, along with acute management of infections as they occur. Prophylactic trimethoprim/sulfamethoxazole $(5 \mathrm{mg} / \mathrm{kg} /$ day based on trimethoprim) reduces the frequency of major infections from about once every year to once every 3.5 years, 
reducing staphylococcal and skin infections without increasing the frequency of serious fungal infections in CGD [17]. Itraconazole prophylaxis showed marked efficacy in the prevention of fungal infection in CGD (100 mg daily for patients $<13$ years or $<50 \mathrm{~kg} ; 200 \mathrm{mg}$ daily for those $\geq 13$ years or $\geq 50 \mathrm{~kg}$ ) [12]. IFN-gamma was shown in a large, multinational, multicenter, placebo-controlled study to reduce the number and severity of infections in CGD by $70 \%$ compared to placebo. These benefits held true regardless of inheritance pattern of CGD, sex, or use of prophylactic antibiotics. Interestingly, no significant difference could be detected in terms of in vitro superoxide generation, bactericidal activity, or cytochrome $b$ levels [47]. Systemic IFN-gamma also augmented neutrophil activity against Aspergillus conidia in vitro [48]. Furthermore, in a study of IFN-gamma in CGD mice, infections were reduced [49]. However, a retrospective Italian study detected no benefit to the addition of IFN-gamma beyond that attributed to antibacterial and antifungals alone [11]. Although the study of IFN-gamma preceded the widespread use of itraconazole, a long-term follow-up of the large prospective trial suggests sustained benefit [13]. Therefore, our current recommendation is to use prophylaxis with trimethoprim/sulfamethoxazole, itraconazole, and IFNgamma $\left(50 \mu \mathrm{g} / \mathrm{m}^{2}\right)$ in CGD.

The erythrocyte sedimentation rate remains a highly sensitive laboratory test for ongoing infection. Since the differential diagnosis for a given process in these patients includes bacteria, fungi, and granulomatous processes, a microbiologic diagnosis is critical. In severe infections, leukocyte transfusions have been used, although their efficacy is anecdotal. In CGD, irradiation of the granulocyte product is not necessary for graft versus host disease prevention and it does inhibit the bactericidal activity of the cells. However, recurrent leukocyte transfusions run the risk of alloimmunization, which is problematic if bone marrow transplantation is to be considered.

Bone marrow transplantation is an attractive technique because it can lead to stable remission of CGD. Several approaches are in use, ranging from full myeloablation resulting, when successful, in complete engraftment [50], to nonmyeloablative conditioning regimens, leading to stable hematopoietic chimerism [51]. Bone marrow transplantation has been performed in the setting of ongoing refractory fungal infection in several instances. While some have been successful, active fungal infections continue to pose a problem for elective bone marrow transplants [52]. Lowintensity nonablative transplants from HLA-identical siblings into CGD patients have had mixed success [53]. Success was greater in children than adults, but transplantrelated toxicities, such as graft versus host disease, were problematic. Recent reports of matched sibling and matched unrelated donor bone marrow transplants from
Newcastle on Tyne [14] show an overall long-term success rate of $90 \%$. Importantly, these British investigators also showed a striking reconstitution of impaired pretransplant growth, suggesting that much of the growth retardation and delay seen in CGD is in fact due to various aspects of hematopoietic dysfunction, ranging from colitis to chronic inapparent infection. Although bone marrow transplantation is an attractive option for the definitive cure of CGD, it should be borne in mind that survival without bone marrow transplantation is roughly comparable, even though certain morbidities like IBD might be ameliorated or prevented by transplantation. However, not all patients have matched related or unrelated donors, effectively excluding a substantial number of patients from this option [54].

CGD is an attractive target for gene therapy for several reasons: it is a single gene defect, it can be reconstituted in vitro, and correction need not be complete in order to provide complete protection [55]. This latter point is proven by the normal lives of many X-linked carriers, as well as by the stable chimeras generated in some transplant protocols. Gene therapy for the paradigmatic disease X-linked severe combined immunodeficiency (SCID) has been effective but complicated by hematopoietic malignancies caused by unanticipated retroviral integration into active sites in the human genome that activated oncogenes [56]. In CGD, many years of study have shown marking of cells in the periphery for several months, but clinical benefit has been elusive, presumably due to the low numbers of corrected cells in the circulation $(<0.01 \%)$ [57]. With the addition of bone marrow conditioning, marking rates have increased and persistence has as well. However, in studies in Germany using a novel vector and bone marrow conditioning, Ott et al. encountered clonal expansions of transduced cells; one patient subsequently died (reviewed in [58]). Unlike the case with SCID, corrected CGD cells do not have a growth or survival advantage in the marrow or in the tissue, as far as we know. Therefore, selection and augmentation of those cells is an area of effort.

Other roles for the NADPH oxidase outside the neutrophil include signaling for $\mathrm{NFKB}$ activation in the setting of liver activation, either by ethanol or by carcinogens $[59,60]$. CGD mice appear to be protected from aortic fatty deposits when crossed to the $\mathrm{ApoE}^{-/}$ model of hypercholesterolemia [61]. Interestingly, that was not the case in the coronary arteries, suggesting that the factors that regulate NADPH activity in the coronaries and the aorta are distinct [62]. NADPH contributes to long-term potentiation, the in vitro brain slice equivalent to memory [63]. In support of those ex vivo mouse data, CGD mice had trouble with certain learning tasks compared to normal mice. In addition, CGD patients had a higher rate of lower intelligence quotient and learning issues than disease controls [64]. NADPH oxidase somatic and hematopoietic 
activity is involved in strokes and in pulmonary vascular permeability [65]. Therefore, it is clear that the NADPH oxidase is active in many more sites than just phagocytes, suggesting that CGD is more complex and has more to teach than about infections and bone marrow transplants alone.

Despite its advanced age and relative rarity, CGD is a disease that is rapidly changing in its diagnosis, management, science, and outlook. It spans the frontiers of basic science, medicine, genetics, infectious diseases, transplantation, and gene therapy.

Acknowledgement This work supported by the Division of Intramural Research, NIAID, NIH.

\section{References}

1. Janeway CA, Craig J, Davidson M, Downey W, Gitlin D, Sullivan JC (1954) Hypergammaglobulinemia associated with severe, recurrent and chronic non-specific infection. Am J Dis Child $88: 388-392$

2. Berendes H, Bridges RA, Good RA (1957) A fatal granulomatous disease of childhood: the clinical study of a new syndrome. Minn Med 40:309

3. Bridges RA, Berendes H, Good RA (1959) A fatal granulomatous disease of childhood. Am J Dis Child 97:387

4. Azimi PH, Bodenbender JG, Hintz RL, Kontras SB (1968) Chronic granulomatous disease in three female siblings. JAMA 206:2865-2870

5. Segal BH, Leto TL, Gallin JI, Malech HL, Holland SM (2000) Genetic, biochemical, and clinical features of chronic granulomatous disease. Medicine (Baltimore) 79:170-200

6. Ushio-Fukai M (2006) Localizing NADPH oxidase-derived ROS. Sci STKE 349:re8

7. Reeves EP, Lu H, Jacobs HL, Messina CGM, Bolsover S, Gabella G, Potma EO, Warley A, Roes J, Segal AW (2002) Killing activity of neutrophils is mediated through activation of proteases by $\mathrm{K}+$ flux. Nature 416:291-297

8. Wolach B, Gavrieli R, de Boer M, Gottesman G, Ben-Ari J, Rottem M, Schlesinger Y, Grisaru-Soen G, Etzioni A, Roos D (2008) Chronic granulomatous disease in Israel: clinical, functional and molecular studies of 38 patients. Clin Immunol 129:103-114

9. Winkelstein JA, Marino MC, Johnston RB Jr, Boyle J, Curnutte J, Gallin JI, Malech HL, Holland SM, Ochs HD, Quie P, Buckley RH, Foster CB, Chanock SJ, Dickler H (2000) Chronic granulomatous disease. Report on a national registry of 368 patients. Medicine (Baltimore) 79:155-169

10. Lublin M, Bartlett DL, Danforth DN, Kauffman H, Gallin JI, Malech HL, Shawker T, Choyke P, Kleiner DE, Schwartzentruber DJ, Chang R, DeCarlo ES, Holland SM (2002) Hepatic abscess in patients with chronic granulomatous disease. Ann Surg 235:383-391

11. Martire B, Rondelli R, Soresina A, Pignata C, Broccoletti T, Finocchi A, Rossi P, Gattorno M, Rabusin M, Azzari C, Dellepiane RM, Pietrogrande MC, Trizzino A, Di Bartolomeo P, Martino S, Carpino L, Cossu F, Locatelli F, Maccario R, Pierani P, Putti MC, Stabile A, Notarangelo LD, Ugazio AG, Plebani A, De Mattia D, IPINET (2008) Clinical features, long-term follow-up and outcome of a large cohort of patients with Chronic Granulomatous Disease: an Italian multicenter study. Clin Immunol 126:155-164
12. Gallin JI, Alling DW, Malech HL, Wesley R, Koziol D, Marciano B, Eisenstein EM, Turner ML, DeCarlo ES, Starling JM, Holland SM (2003) Itraconazole to prevent fungal infections in chronic granulomatous disease. N Engl J Med 348:2416-2422

13. Marciano BE, Wesley R, De Carlo ES, Anderson VL, Barnhart LA, Darnell D, Malech HL, Gallin JI, Holland SM (2004) Longterm interferon-gamma therapy for patients with chronic granulomatous disease. Clin Infect Dis 39:692-699

14. Soncini E, Slatter MA, Jones LB, Hughes S, Hodges S, Flood TJ, Barge D, Spickett GP, Jackson GH, Collin MP, Abinun M, Cant AJ, Gennery AR (2009) Unrelated donor and HLA-identical sibling haematopoietic stem cell transplantation cure chronic granulomatous disease with good long-term outcome and growth. Br J Haematol 145:73-83

15. Kobayashi S, Murayama S, Takanashi S, Takahashi K, Miyatsuka S, Fujita T, Ichinohe S, Koike Y, Kohagizawa T, Mori H, Deguchi Y, Higuchi K, Wakasugi H, Sato T, Wada Y, Nagata M, Okabe N, Tatsuzawa $\mathrm{O}(2008)$ Clinical features and prognoses of 23 patients with chronic granulomatous disease followed for 21 years by a single hospital in Japan. Eur J Pediatr 167:1389-1394

16. Mouy R, Fischer A, Vilmer E, Seger R, Griscelli C (1989) Incidence, severity and prevention of infections in chronic granulomatous disease. J Pediatr 114:555-560

17. Margolis DM, Melnick DA, Alling DW, Gallin JI (1990) Trimethoprim-sulfamethoxazole prophylaxis in the management of chronic granulomatous disease. J Infect Dis 162:723-726

18. Ross JP, Holland SM, Gill VJ, DeCarlo ES, Gallin JI (1995) Severe Burkholderia (Pseudomonas) gladioli infection in chronic granulomatous disease: report of two successfully treated cases. Clin Infect Dis 21:1291-1293

19. Kennedy MP, Coakley RD, Donaldson SH, Aris RM, Hohneker K, Wedd JP, Knowles MR, Gilligan PH, Yankaskas JR (2007) Burkholderia gladioli: five year experience in a cystic fibrosis and lung transplantation center. J Cyst Fibros 6:267-273

20. Sirinavin S, Techasaensiri C, Benjaponpitak S, Pornkul R, Vorachit M (2005) Invasive Chromobacterium violaceum infection in children: case report and review. Pediatr Infect Dis J 24:559-561

21. Mailman TL, Schmidt MH (2005) Francisella philomiragia adenitis and pulmonary nodules in a child with chronic granulomatous disease. Can J Infect Dis Med Microbiol 16:245-248

22. Greenberg DE, Ding L, Zelazny AM, Stock F, Wong A, Anderson VL, Miller G, Kleiner DE, Tenorio AR, Brinster L, Dorward DW, Murray PR, Holland SM (2006) A novel bacterium associated with lymphadenitis in a patient with chronic granulomatous disease. PLoS Pathog 2:e28

23. López FC, de Luna FF, Delgado MC, de la Rosa II, Valdezate S, Nieto JA, Casal M (2008) Granulibacter bethesdensis isolated in a child patient with chronic granulomatous disease. J Infect 57:275-277

24. Williamson PR, Kwon-Chung KJ, Gallin JI (1992) Successful treatment of Paecilomyces varioti infection in a patient with chronic granulomatous disease and a review of Paecilomyces species infections. Clin Infect Dis 14:1023-1026

25. Segal BH, DeCarlo ES, Kwon-Chung KJ, Malech HL, Gallin JI, Holland SM (1998) Aspergillus nidulans infection in chronic granulomatous disease. Medicine (Baltimore) 77:345-354

26. Vinh DC, Shea YR, Sugui JA, Parrilla-Castellar ER, Freeman AF et al (2009) Invasive aspergillosis due to Neosartorya udagawae. Clin Infect Dis (in press)

27. Vinh DC, Freeman AF, Shea YR, Malech HL, Abinun M, Weinberg GA, Holland SM (2009) Mucormycosis in chronic granulomatous disease: association with iatrogenic immunosuppression. J Allergy Clin Immunol (in press)

28. Morgenstern DE, Gifford MA, Li LL, Doerschuk CM, Dinauer MC (1997) Absence of respiratory burst in X-linked chronic 
granulomatous disease mice leads to abnormalities in both host defense and inflammatory response to Aspergillus fumigatus. J Exp Med 185:207-218

29. Siddiqui S, Anderson VL, Hilligoss DM, Abinun M, Kuijpers TW, Masur H, Witebsky FG, Shea YR, Gallin JI, Malech HL, Holland SM (2007) Fulminant mulch pneumonitis: an emergency presentation of chronic granulomatous disease. Clin Infect Dis 45:673-681

30. Marciano BE, Rosenzweig SD, Kleiner DE, Anderson VL, Darnell DN, Anaya-O'Brien S, Hilligoss DM, Malech HL, Gallin JI, Holland SM (2004) Gastrointestinal involvement in chronic granulomatous disease. Pediatrics 114:462-468

31. Marks DJ, Miyagi K, Rahman FZ, Novelli M, Bloom SL, Segal AW (2009) Inflammatory bowel disease in CGD reproduces the clinicopathological features of Crohn's disease. Am J Gastroenterol 104:117-124

32. Hussain N, Feld JJ, Kleiner DE, Hoofnagle JH, Garcia-Eulate R, Ahlawat S, Koziel DE, Anderson V, Hilligoss D, Choyke P, Gallin JI, Liang TJ, Malech HL, Holland SM, Heller T (2007) Hepatic abnormalities in patients with chronic granulomatous disease. Hepatology 45:675-683

33. Feld JJ, Hussain N, Wright EC, Kleiner DE, Hoofnagle JH, Ahlawat S, Anderson V, Hilligoss D, Gallin JI, Liang TJ, Malech HL, Holland SM, Heller T (2008) Hepatic involvement and portal hypertension predict mortality in chronic granulomatous disease. Gastroenterology 134:1917-1926

34. Walther MM, Malech HL, Berman A, Choyke P, Venzon DJ, Linehan WM, Gallin JI (1992) The urologic manifestations of chronic granulomatous disease. J Urol 147:1314-1318

35. Bendhack ML, Vögeli T, Schroten H, Gerharz CD, Ackermann R (1997) Chronic granulomatous disease masquerading as a bladder tumor: a potential source of diagnostic error. Eur Urol 32:380-384

36. Kis E, Verebély T, Mészner Z (2002) Inflammatory pseudotumor of the bladder in chronic granulomatous disease. Pediatr Nephrol 17:220-221

37. Hauck F, Heine S, Beier R, Wieczorek K, Müller D, Hahn G, Gahr M, Rösen-Wolff A, Roesler J (2008) Chronic granulomatous disease (CGD) mimicking neoplasms: a suspected mediastinal teratoma unmasking as thymic granulomas due to X-linked CGD, and 2 related cases. J Pediatr Hematol Oncol 30:877-880

38. Barese CN, Podestá M, Litvak E, Villa M, Rivas EM (2004) Recurrent eosinophilic cystitis in a child with chronic granulomatous disease. J Pediatr Hematol Oncol 26:209-212

39. Elloumi HZ, Holland SM (2007) Diagnostic assays for chronic granulomatous disease and other neutrophil disorders. Methods Mol Biol 412:505-523

40. Mauch L, Lun A, O'Gorman MR, Harris JS, Schulze I, Zychlinsky A, Fuchs T, Oelschlägel U, Brenner S, Kutter D, Rösen-Wolff A, Roesler J (2007) Chronic granulomatous disease (CGD) and complete myeloperoxidase deficiency both yield strongly reduced dihydrorhodamine 123 test signals but can be easily discerned in routine testing for CGD. Clin Chem 53:890896

41. Ferguson PJ, Lokuta MA, El-Shanti HI, Muhle L, Bing X, Huttenlocher A (2008) Neutrophil dysfunction in a family with a SAPHO syndrome-like phenotype. Arthritis Rheum 58:3264-3269

42. Roos D, van Zwieten R, Wijnen JT, Gomez-Gallego F, de Boer M, Stevens D, Pronk-Admiraal CJ, de Rijk T, van Noorden CJ, Weening RS, Vulliamy TJ, Ploem JE, Mason PJ, Bautista JM, Khan PM, Beutler E (1999) Molecular basis and enzymatic properties of glucose-6-phosphate dehydrogenase volendam, leading to chronic nonspherocytic anemia, granulocyte dysfunction, and increased susceptibility to infections. Blood 94:29552962

43. Rösen-Wolff A, Soldan W, Heyne K, Bickhardt J, Gahr M, Roesler J (2001) Increased susceptibility of a carrier of X-linked chronic granulomatous disease (CGD) to Aspergillus fumigatus infection associated with age-related skewing of lyonization. Ann Hematol 80:113-115

44. Brandrup F, Koch C, Petri M, Schiodt M, Johansen KS (1981) Discoid lupus erythematosus-like lesions and stomatitis in female carriers of X-linked chronic granulomatous disease. Br J Dermatol 104:495-505

45. Kragballe K, Borregaard N, Brandrup F, Koch C, Staehrjohansen K (1981) Relation of monocyte and neutrophil oxidative metabolism to skin and oral lesions in carriers of chronic granulomatous disease. Clin Exp Immunol 43:390-398

46. Rupec RA, Petropoulou T, Belohradsky BH, Walchner M, Liese JG, Plewing G, Messer G (2000) Lupus erythematosus tumidus and chronic discoid lupus erythematosus in carriers of X-linked chronic granulomatous disease. Eur J Dermatol 10:184-189

47. International Chronic Granulomatous Disease Cooperative Study Group (1991) A controlled trial of interferon gamma to prevent infection in chronic granulomatous disease. $N$ Engl J Med 324:509-516

48. Rex JH, Bennett JE, Gallin JI, Malech HL, DeCarlo ES, Melnick DA (1991) In vivo interferon-gamma therapy augments the in vitro ability of chronic granulomatous disease neutrophils to damage Aspergillus hyphae. J Infect Dis 163:849-852

49. Jackson SH, Miller GF, Segal BH, Mardiney M 3rd, Domachowske JB, Gallin JI, Holland SM (2001) IFN-gamma is effective in reducing infections in the mouse model of chronic granulomatous disease (CGD). J Interferon Cytokine Res 21:567-573

50. Seger RA, Gungor T, Belohradsky BH, Blanche S, Bordigoni P, Di Bartolomeo P, Flood T, Landais P, Müller S, Ozsahin H, Passwell JH, Porta F, Slavin S, Wulffraat N, Zintl F, Nagler A, Cant A, Fischer A (2002) Treatment of chronic granulomatous disease with myeloablative conditioning and an unmodified hemopoietic allograft: a survey of the European experience, 1985-2000. Blood 100:4344-4350

51. Kamani N, August CS, Campbell DE, Hassan NF, Douglas SD (1988) Marrow transplantation in chronic granulomatous disease: an update with 6 year follow-up. J Pediatr 113:697-700

52. Ozsahin H, von Planta M, Muller I, Steinert HC, Nadal D, Lauener R, Tuchschmid P, Willi UV, Ozsahin M, Crompton NE, Seger RA (1998) Successful treatment of invasive aspergillosis in chronic granulomatous disease by bone marrow transplantation, granulocyte colony-stimulating factor-mobilized granulocytes, and liposomal amphotericin-B. Blood 92:2719-2724

53. Horwitz ME, Barrett AJ, Brown MR, Carter CS, Childs R, Gallin JI, Holland SM, Linton GF, Miller JA, Leitman SF, Read EJ, Malech HL (2001) Treatment of chronic granulomatous disease with nonmyeloablative conditioning and T-cell-depleted hematopoietic allograft. N Engl J Med 344:881-888

54. Seger RA (2008) Modern management of chronic granulomatous disease. Br J Haematol 140:255-266

55. Kang EM, Malech HL (2008) Advances in treatment for chronic granulomatous disease. Immunol Res 43:77-84

56. Cavazzana-Calvo M, Fischer A (2007) Gene therapy for severe combined immunodeficiency: are we there yet? J Clin Invest 117:1456-1465

57. Malech HL, Maples PB, Whiting-Theobald N, Linton GF, Sekhsaria S, Vowells SJ, Li F, Miller JA, DeCarlo E, Holland SM, Leitman SF, Carter CS, Butz RE, Read EJ, Fleisher TA, Schneiderman RD, Van Epps DE, Spratt SK, Maack CA, Rokovich JA, Cohen LK, Gallin JI (1997) Prolonged production of NADPH oxidase-corrected granulocytes after gene therapy of chronic granulomatous disease. Proc Natl Acad Sci U S A 94:12133-12138

58. Ryser MF, Roesler J, Gentsch M, Brenner S (2007) Gene therapy for chronic granulomatous disease. Expert Opin Biol Ther 7:1799-1809 
59. Kono H, Rusyn I, Yin M, Gäbele E, Yamashina S, Dikalova A, Kadiiska MB, Connor HD, Mason RP, Segal BH, Bradford BU, Holland SM, Thurman RG (2000) NADPH oxidase-derived free radicals are key oxidants in alcohol-induced liver disease. J Clin Invest 106:867-872

60. Rusyn I, Kadiiska MB, Dikalova A, Kono H, Yin M, Tsuchiya K, Mason RP, Peters JM, Gonzalez FJ, Segal BH, Holland SM, Thurman RG (2001) Phthalates rapidly increase production of reactive oxygen species in vivo: role of Kupffer cells. Mol Pharmacol 59:744-750

61. Barry-Lane PA, Patterson C, van der Merwe M, Hu Z, Holland $\mathrm{SM}$, Yeh ET, Runge MS (2001) $\mathrm{p} 47^{\text {phox }}$ is required for atherosclerotic lesion progression in $\mathrm{ApoE}(-/-)$ mice. J Clin Invest 108:1513-1522

62. Hsich E, Segal BH, Pagano PJ, Rey FE, Paigen B, Deleonardis J, Hoyt RF, Holland SM, Finkel T (2000) Vascular effects following homozygous disruption of $\mathrm{p} 47$ (phox): an essential component of NADPH oxidase. Circulation 101:1234-1236

63. Kishida KT, Hoeffer CA, Hu D, Pao M, Holland SM, Klann E (2006) Synaptic plasticity deficits and mild memory impairments in mouse models of chronic granulomatous disease. Mol Cell Biol 26:5908-5920

64. Pao M, Wiggs EA, Anastacio MM, Hyun J, DeCarlo ES, Miller JT, Anderson VL, Malech HL, Gallin JI, Holland SM (2004) Cognitive function in patients with chronic granulomatous disease: a preliminary report. Psychosomatics 45:230 234

65. Walder CE, Green SP, Darbonne WC, Mathias J, Rae J, Dinauer MC, Curnutte JT, Thomas GR (1997) Ischemic stroke injury is reduced in mice lacking a functional NADPH oxidase. Stroke 28:2252-2258 